\title{
STUDY OF SOME FACTORS EFFECTING ON PRODUCTIVITY OF SOLAR DISTILLERS
}

\author{
Keshek, M.H. ${ }^{(1)}$; Mohamed, M.A. ${ }^{(2)}$ and Maha A. El-Shafey ${ }^{(3)}$
}

\section{ABSTRACT}

The aim of this research was increasing the productivity of solar distillation. In order to reach this aim a solar distiller was created with three glass sides sloping $30^{\circ}$ at the horizontal level, and the experiments were carried out on the solar distillation unit during the period from $24^{\text {th }}$ August, 2016 till 24 $4^{\text {th }}$ May, 2017 at the Agricultural Engineering and Bio Systems Department, Faculty of Agriculture, Menoufia University. Three gap lengths were used between the water level and the inner glass cover, those were 3, 6, and $9 \mathrm{~cm}$. As the result of change the gap length between the water level and the inner glass cover the total volume of basins were changed from 15.5, 13, and $11 \mathrm{~L}$ respectively. The total basin volume divided to three sections, to investigate the effect of water volume. The three water volumes were $100 \%, 75 \%$, and 50\%. Every section was supplied with one, two or three heaters. The one heater power was $15 \mathrm{~W}$. The results showed that, by increase in distance between the basins edge and the inner edge of the glass cover an increase occurs in the percentage of temperature difference with maximum value was $52 \%$ at distance $9 \mathrm{~cm}$ from each edge, an increase occurs in the productivity with maximum productivity was $3.3 \mathrm{~L} / \mathrm{m}^{2}$ at distance $9 \mathrm{~cm}$ from each edge and an increase occurs in the efficiency with maximum efficiency was $70 \%$ at distance $9 \mathrm{~cm}$ from each edge

Keywords: Water distillation; solar energy; the still productivity; and distillation efficiency.

\section{INTRODUCTION}

$\mathrm{D}$ esalination is growing rapidly worldwide. However, there are still obstacles to its wider implementation and acceptance such as: (a) high costs and energy use for fresh water production; (b) environmental impacts from concentrate disposal; (c) a complex, convoluted and time-consuming project permitting process; and (d) limited public understanding of the role, importance, benefits and environmental challenges of desalination (Zotalis et al.2014).

(1) Associate professor, Agric. Eng. Dept., Faculty of Agric., Menoufia University.

(2) Professor, Agric. Eng. Dept., Faculty of Agric., Menoufia University.

(3) Postgraduate student, Agric. Eng. Dept., Faculty of Agric., Menoufia University. 
The basic principles of solar water distillation are simple, yet effective, as distillation replicates the way nature makes rain. The sun's energy heats water to the point of evaporation. As the water evaporates, water vapor rises, condensing on the glass surface for collection. This process removes impurities, such as salt, sand and heavy metals, and eliminates microbiological organisms.

The end result is water cleaner than the purest rainwater (Bhupendra et al.2013). Improving solar still productivity has been the subject of intensive research efforts and remains a challenge to the scientists. This improvement can be achieved through a proper modification in the still design and its operation mode by adopting different techniques (Kabeel et al. 2014). Solar desalination is one of the most appropriate solutions to overcome the water shortage problem which threatens the human life in many regions around the world (Abdelouahab and Rahmani 2017). There is a relation between the cover tilt angle and productivity of simple solar still in various seasons is established together with a relation between the optimum tilt angle and the latitude angle by an extensive review of the literature. He found that increasing the tilt angle increase the productivity in winter while, in summer the trend is the opposite. He added that increasing the tilt angle would increase the productivity throughout the year and optimum cover tilt angle that is close to the latitude angle of the site (Khalifa 2011). The efficiency of the singlebasin solar still is in the range of $30-50 \%$. The major problem behind this is the loss of latent heat from condensation through the glass cover of the stills. The used of a plate solar collector to supply the heat to the still was slightly improved the desalination efficiency, but the increase in the cost of the unit was significant. They added that some investigators was make the water flow over the glass cover to Preheating of the feed water by passing it over the glass cover allowed only partial utilization of the latent heat with only a limited increase in the production. However, the flow of water over the glass cover reduced the amount of solar radiation received by the water in the still and the accumulation of salt was also some of the defects of these units (Yahya 2011). The saline water temperature controls the evaporation rate as the latter increases with the increase of the temperature of the unpurified water. Parabolic concentrators, plate collector, mini solar pond are combined with the solar still to increase its temperature. Large amounts of energy may be 
needed for increasing the temperature of the entire solar still water. The evaporation rate is directly proportional with the temperature of the water free surface area. Therefore, we can use baffle suspended absorber plates to increase the water free surface area (Velmurugan and Srithar 2011). The main factors affecting the productivity of a solar still as mentioned before are solar intensity, wind velocity, environmental temperature, water-glass temperature difference, depth of water, temperature of inlet water, absorber plate area and glass cover angle. Metrological parameters such as solar intensity, wind velocity and environmental temperature cannot be controlled (Sharshir et al. 2015). Solar still is suited to villages and to mass production water purification. Around the world, concerns over water quality are increasing, and in special situations a solar still can provide a water supply more economically than any other method. The two big advantages of a solar still are that it uses low grade solar energy which is available forever and there is no greenhouse pollutant evolution as is the case with other desalination techniques using fossil fuels. Further it can be utilized in remote places where there is no electricity and fuels (Bhupendra et al, 2013). So that the objective of this study was studying some factors effect on solar desalination such as distance between the basins edge and the inner edge of the glass cover, water basin volume, and number of addition heaters on productivity and efficiency of solar distillers.

\section{MATERIALS AND METHODS}

\subsection{Equipment and materials}

\subsubsection{Solar distillers.}

The solar distillers were created in the form of pyramid, as shown in figure (1). The three sides of the still were sloping $30^{\circ}$ to its horizontal base, and the fourth side of the still was vertical on the still's base. Solar distiller base area was $0.82 \mathrm{~m}^{2}$.

\subsubsection{Solar distiller's basins}

Basins were isosceles trapezium. Their thicknesses were $3 \mathrm{~cm}$. Three gaps between the basins edge and the inner edge of the glass cover, those gaps were 3,6 , and $9 \mathrm{~cm}$. According to the length of the gap the total volume of the basins were $15.5,13$, and $11 \mathrm{~L}$ (liter) for gap length 3,6 , and $9 \mathrm{~cm}$ respectively. Each basin its total volume divided to three parts, 
to investigate the effect of water volume on the productivity. The three parts were $100 \%, 75 \%$, and $50 \%$ from the total basins volumes.

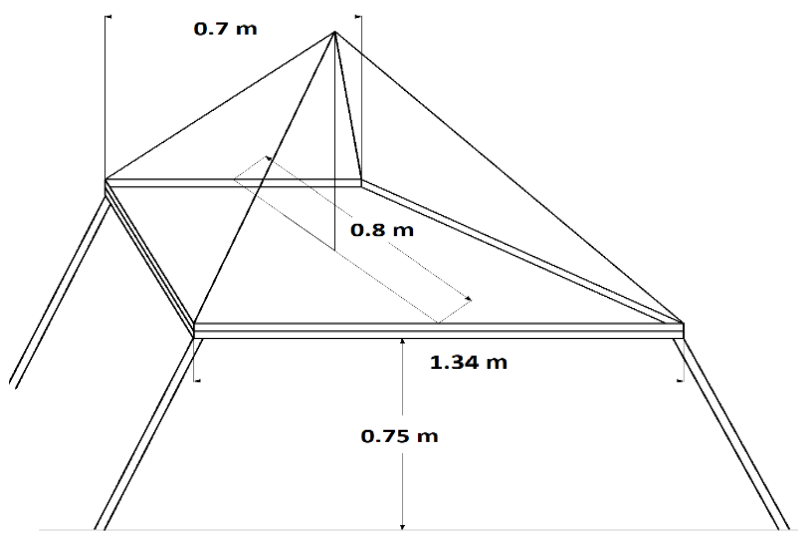

Figure (1) Schematic diagram of the solar still.

\subsubsection{Water specifications}

Due to seawater wasn't available in experiment's place, brackish water was used. Salinity was $170 \mathrm{ppm}$. Salt was added to simulate the salinity of seawater ( $35000 \mathrm{ppm})$, in the rate of 35 gram salt per liter of water. The following table (3.2) showed the quantity of water in liter which was used in each basin.

\begin{tabular}{|l|l|l|l|l|}
\hline & Section 1 & Sec. 2 & Sec. 3 & Total \\
\hline First basin & 7.5 & 4.25 & 3.75 & 15.5 \\
\hline Second basin & 6.5 & 3.2 & 3.3 & 13 \\
\hline Third basin & 5.5 & 2.5 & 3 & 11 \\
\hline
\end{tabular}

\subsubsection{Heaters}

Handmade heaters were used in these experiments. Its length was $15 \mathrm{~cm}$. Each one of them was consists of glass tube included welding heater, to isolate it from water. Sand was put between them, to let air out. The power of this heater was 15 -Watt, figure (2).

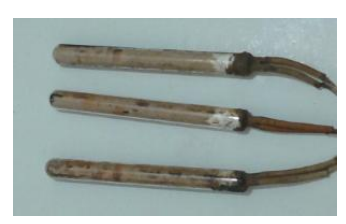

Figure (2) Heaters

\section{Measurements}

\section{Temperatures measurements}

LabJackU3 HV (High-Voltage) was used to record the air and inner water temperatures, which were measured during the experiments. Out 
temperatures of the pyramid still and air temperature were measured by four thermometers. Temperature range of the thermometer reached to $110^{\circ}$ Celsius, figure (3).

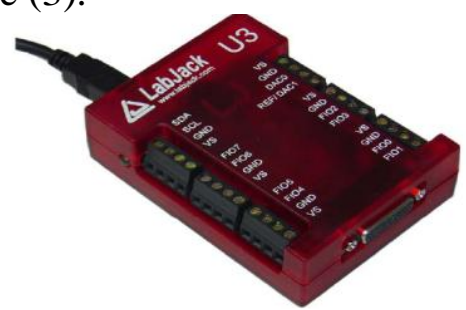

Figure (3) LabJackU3 HV (High-Voltage)

\section{Quantity of water}

Measuring cylinder was used to measure the quantity of water entering still and distilled water.

\section{TDS meter}

A TDS meter indicates the total dissolved solids (TDS) of a solution, i.e. the concentration of dissolved solid particles.

\section{Daily efficiency of solar (passive and active) distillers.}

The overall thermal efficiency $\left(\eta_{\text {p-ss }}\right)$ for S-SSU is represented as the ratio between net energy output from solar distiller to net available solar radiation intensity which is given by Tiwari et al. (2007) as follows:

$$
\eta_{\mathrm{p}-\mathrm{ss} 1}=(\text { daily yield } \times \mathrm{L}) /\left(\mathrm{A}_{\mathrm{s}} \times \Sigma \mathrm{I}_{\mathrm{s}} \times 3600\right) \times 100 \%
$$

Where daily yield $\mathrm{L} / \mathrm{hr}$, $\mathrm{L}$ was the water vaporization latent heat $\mathrm{kJ} / \mathrm{kg}, \mathrm{A}_{\mathrm{s}}$ was area of the basin still $\mathrm{m}^{2}$, and $\Sigma \mathrm{I}_{\mathrm{s}}$ total solar irradiance on solar distiller $\mathrm{kW} / \mathrm{m}^{2}$.

The overall thermal efficiency of the proposed still ( $\eta_{\text {A-ss-HPVT }}$ ) was calculated by summing the thermal efficiency of the active still and the electrical efficiency of the solar PV. With the reference of Tiwari et al. (2007), the overall efficiency was calculated by the following equations:

$$
\eta_{\mathrm{p}-\mathrm{ss} 2}=(\text { daily yield } \times \mathrm{L}) /\left[\left(\mathrm{A}_{\mathrm{s}} \times \Sigma \mathrm{I}_{\mathrm{s}}\right)+\left(\mathrm{n} \times \Sigma \mathrm{I}_{\mathrm{p}}\right) \times 3600\right] \times 100 \%
$$

Where $\mathrm{n}$ was number of using heaters, and $\Sigma \mathrm{I}_{\mathrm{p}}$ the heater power, which was $15 \mathrm{~W}$.

The percentage of temperature difference between inside and outside was calculated by the following equations:

$$
\text { (Tin-Tout)/Tin } \times 100
$$

Then the average temperature difference is calculated during the day (av $\mathrm{t}, \%)$. 


\section{3-RESULTS AND DISCUSSION}

\subsection{Productivity of solar distillers}

\subsubsection{Productivity with different sizes of basins}

The productivity for the tested period of the day for the first, second, and third basin when using none, 1, 2 and 3 heaters in each section, and when the basin was filled with water volume $100 \%, 75 \%$, and $50 \%$, those volumes located when the distance between basin and glass was 3, 6, and $9 \mathrm{~cm}(15.5,13,11 \mathrm{~L}$ respectively). The highest productivity were $1.4,1.8$, $3.3 \mathrm{~L} / \mathrm{m}^{2}$ respectively.

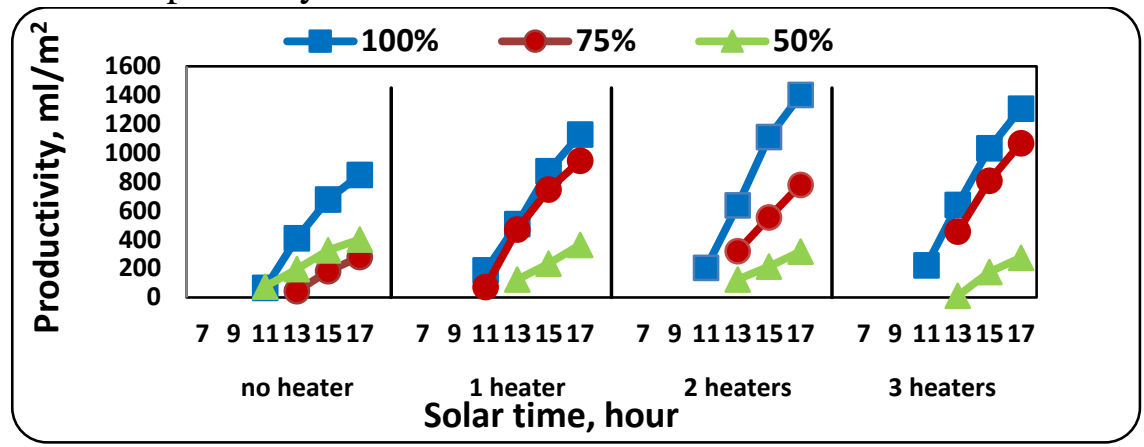

(a) for basin volume 15.5 (liter).

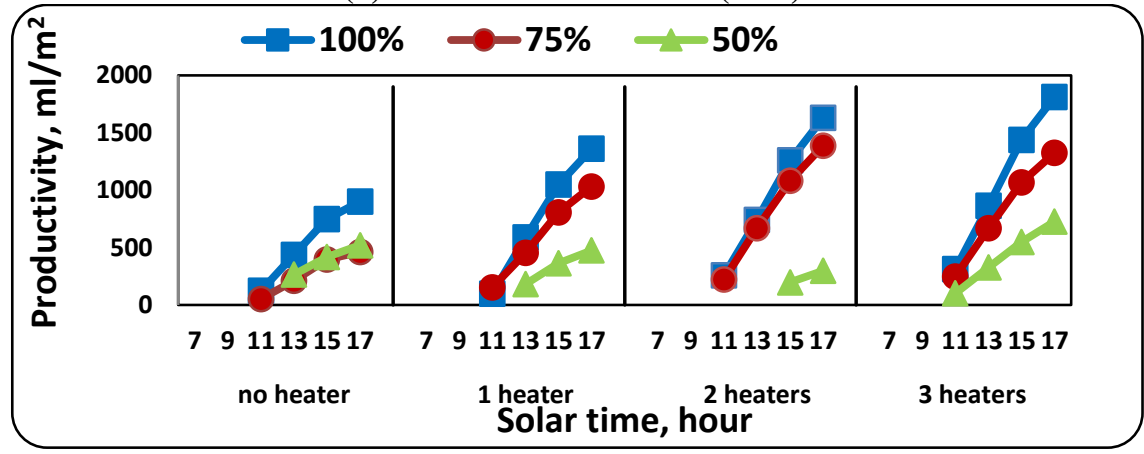

(b) for basin volume 13 (liter).

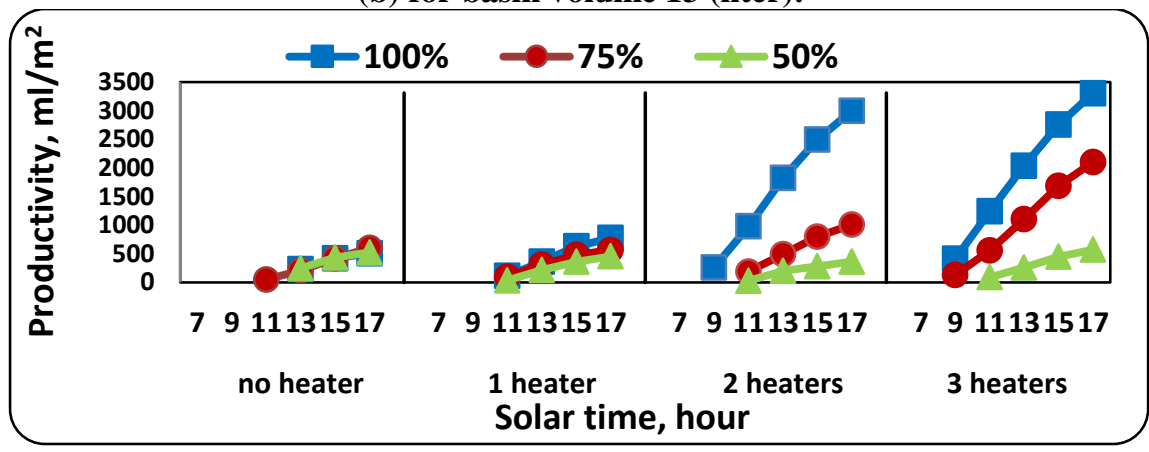

(c) for basin volume 11 (liter).

Fig.4. Productivity for basins. 


\subsubsection{Productivity and average ratio of temperature difference.}

Figures (5) a, b, and c present the relation between productivity and average percentages of temperature difference (av $t$ ) with the different treatments, and from figures it can conclude that, maximum productivity was $3.3 \mathrm{~L} / \mathrm{m}^{2}$ and minimum productivity was $0.3 \mathrm{~L} / \mathrm{m}^{2}$.

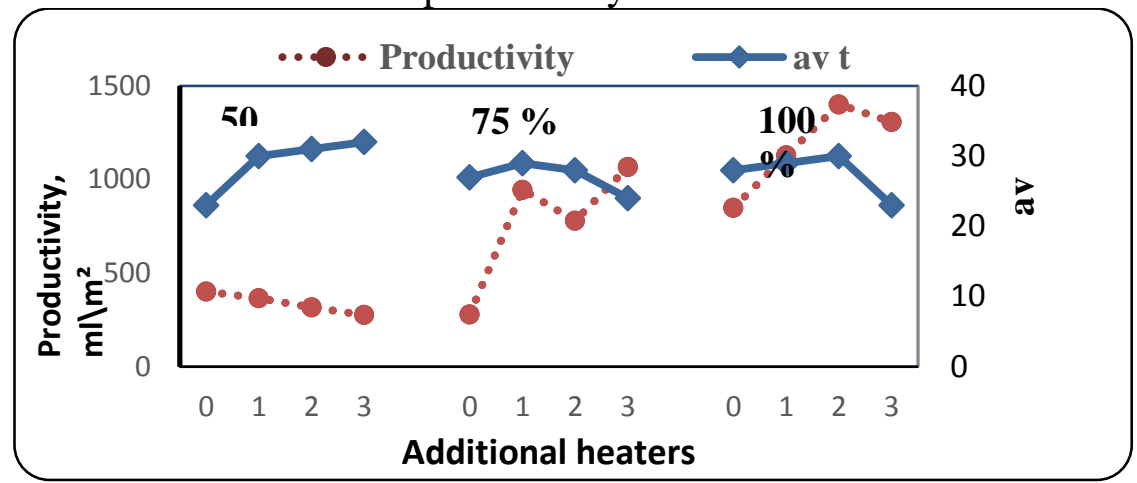

(a) for basin volume 15.5 (liter).

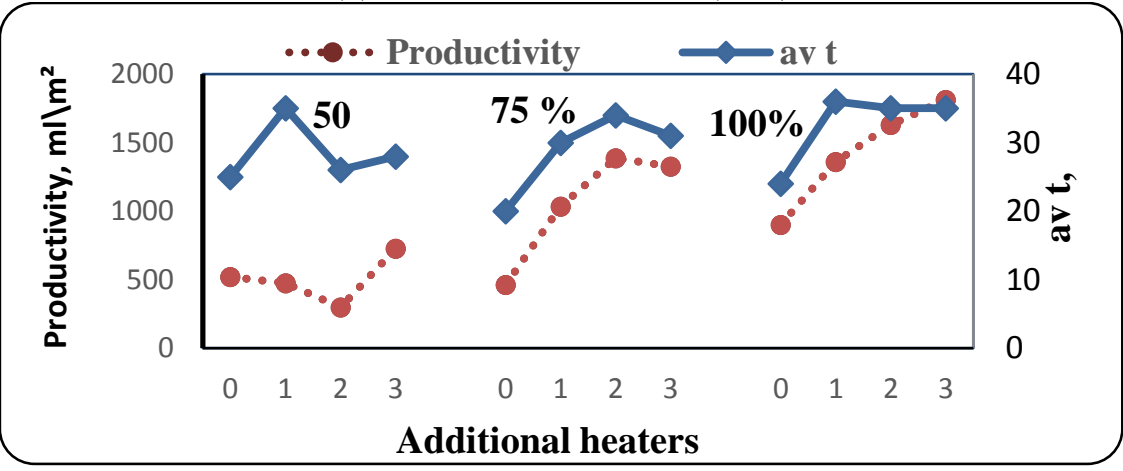

(b) for basin volume 13 (liter).

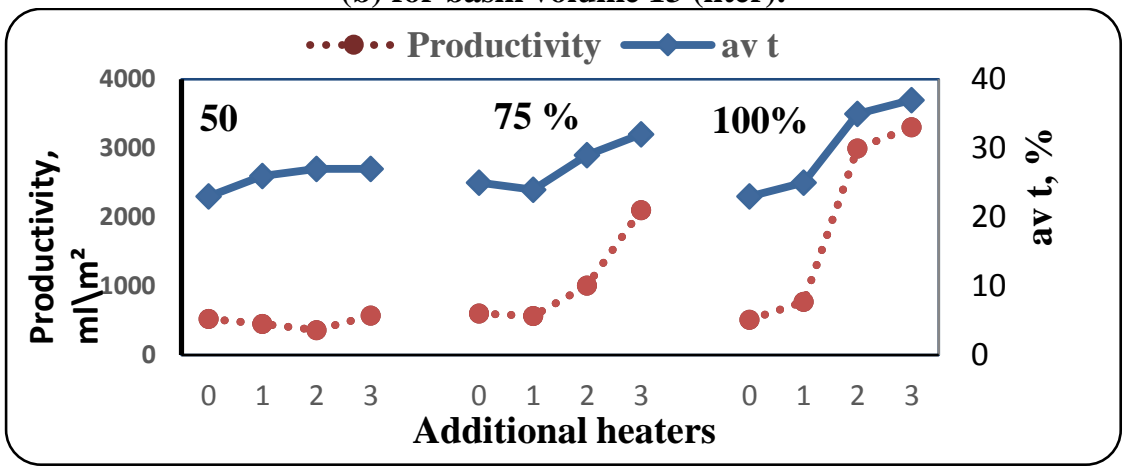

(c) for basin volume 11 (liter).

Fig.5. The productivity and average ratio of temperature difference (av $t$,). 


\subsection{Efficiency of solar distiller.}

\subsubsection{Thermal efficiency solar distillers.}

Figures (6) a, b, c, and d show the efficiency for the distiller for all work's days. In the figures $\mathrm{a}$, and $\mathrm{b}$ the second basin which filled with water by 13L (100\%) gave the highest efficiency in two cases, without using heaters and when using one heater. In the figures $\mathrm{c}$, and $\mathrm{d}$ the third basin which filled with water by 11L (100\%) gave the highest efficiency in two cases, when using two and three heaters. The maximum efficiency was $70 \%$, The minimum efficiency was $12 \%$.

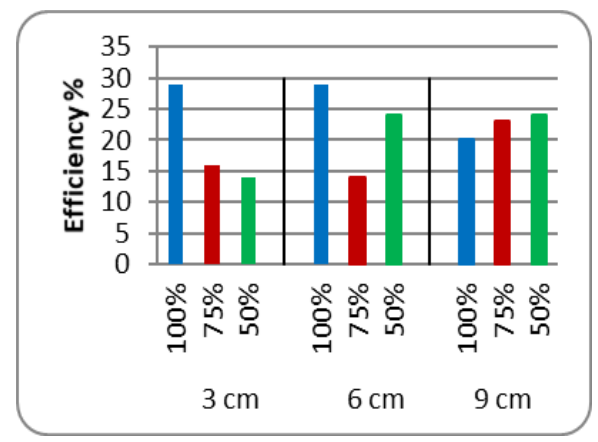

(a) 0 heater.

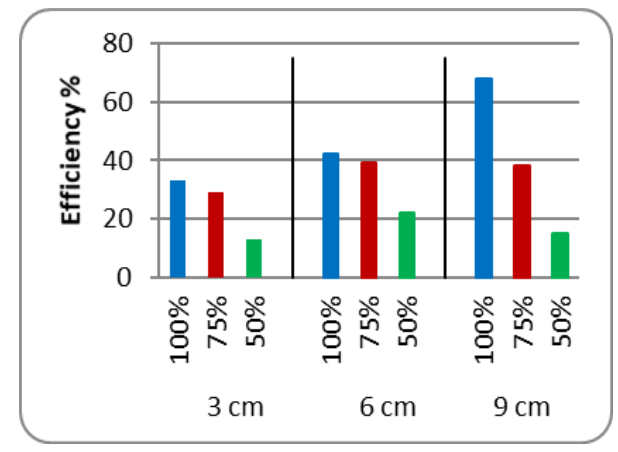

(c) 2 heaters

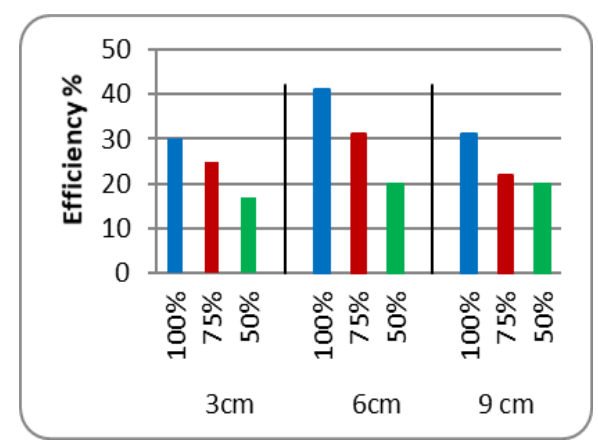

(b) 1 heater.

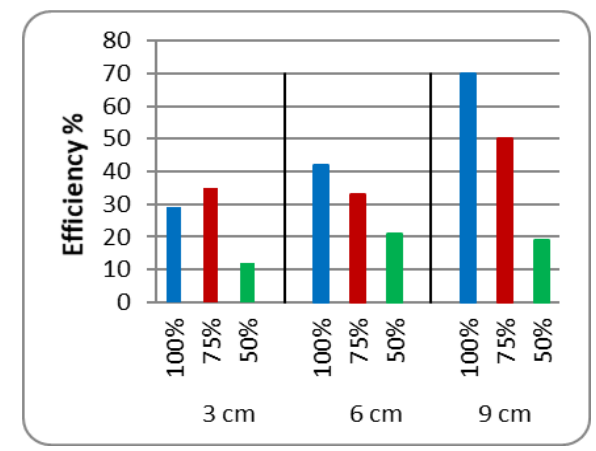

(d) 3 heaters

Fig.6. Thermal efficiency of solar distiller.

Figures (7) a, b and c present the relation between efficiency and average percentage of temperature difference (av t) with different treatments. From this figures it can conclude that, by increase of basin volume, a decrease occurs in efficiency of the still. 


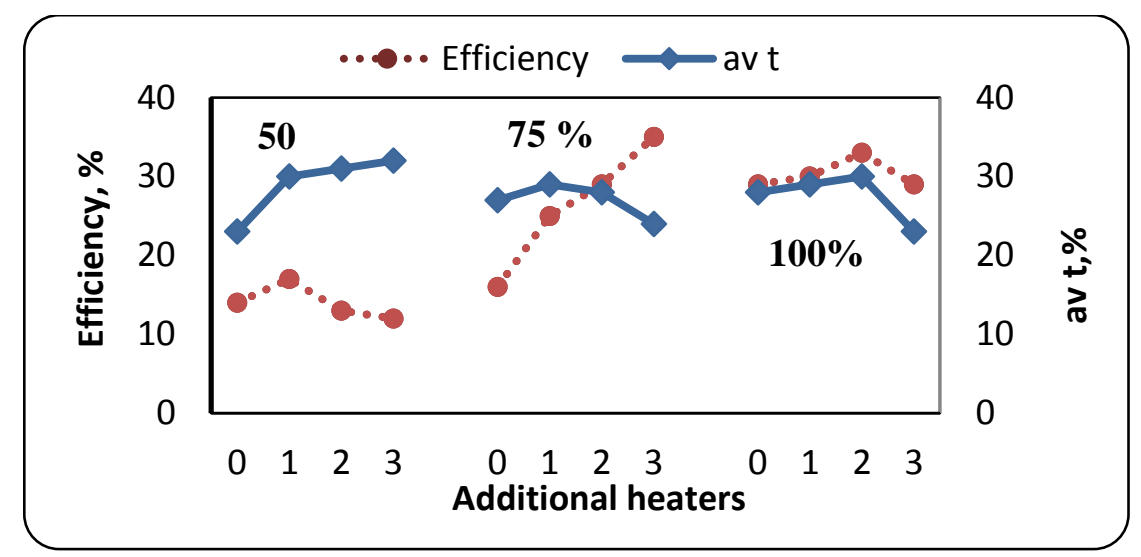

(a) for basin volume 15.5 (liter).

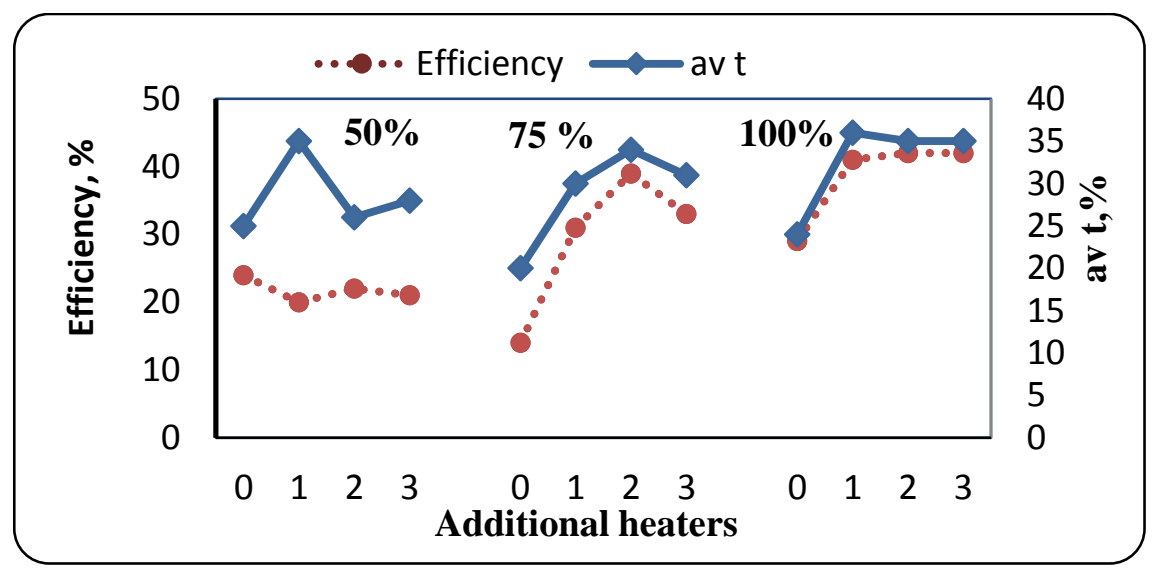

(b) for basin volume 13 (liter).

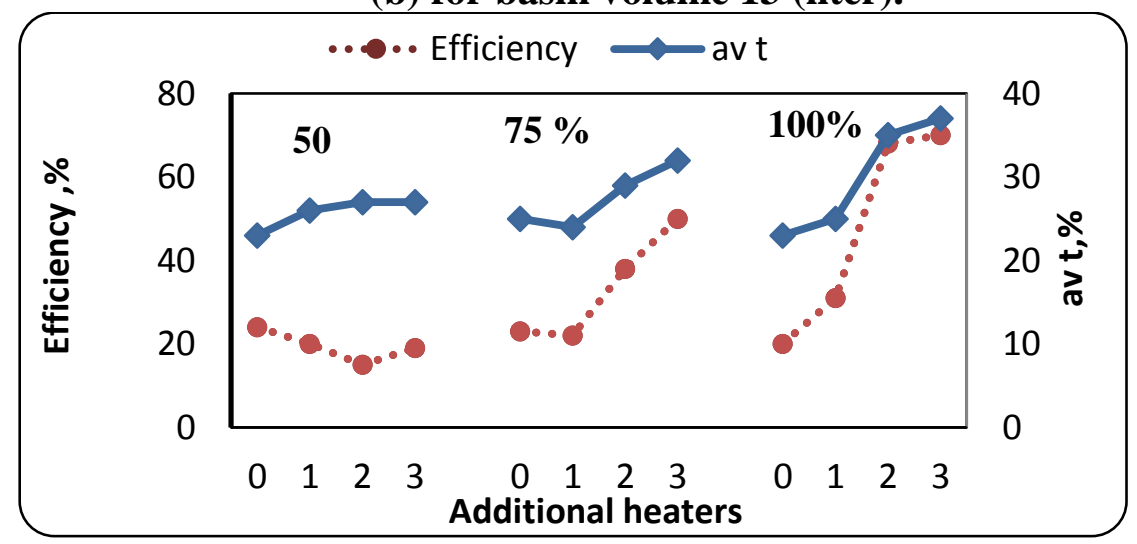

(c) for basin volume 11 (liter).

Fig. 7. Thermal efficiency average ratio of temperature difference (av $t$,). 


\section{Effectiveness of water production}

Figures (8) a, b, c, and d show the efficiency by divide output and input water for the distiller. From these figures it can conclude that, the maximum efficiency was $24.6 \%$ at distance $9 \mathrm{~cm}$ from each edge and full $100 \%$ with water, and that when using 3 heaters in each section. The minimum efficiency was $2 \%$ at distance $3 \mathrm{~cm}$ from each edge and full $75 \%$ with water, and that without using heaters.

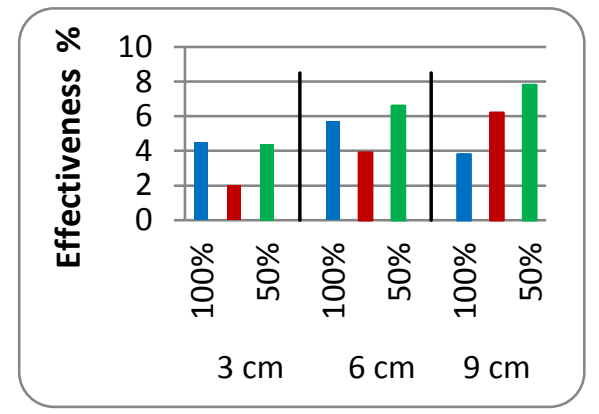

(a) 0 heater.

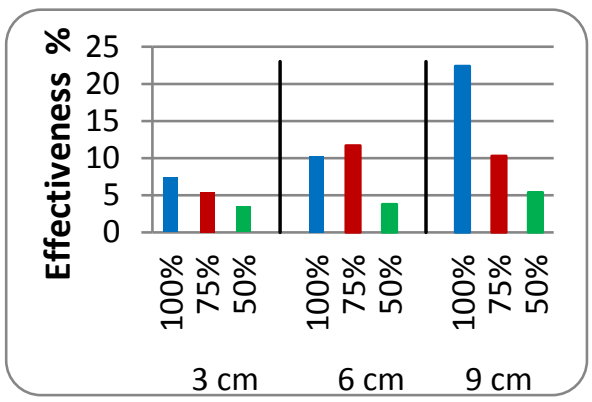

(c) 2 heaters

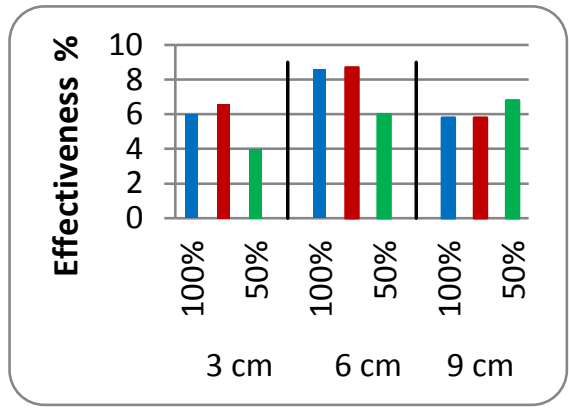

(b) 1 heater.

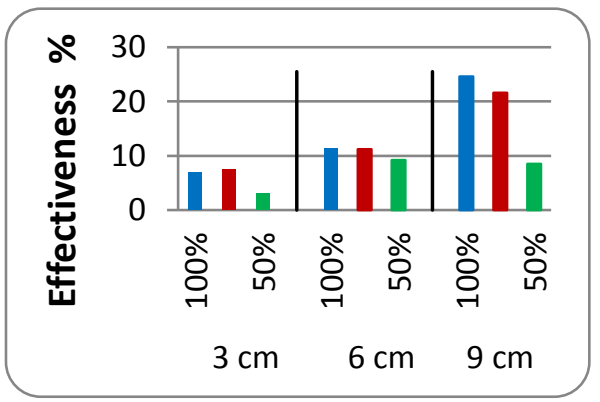

(d) 3 heaters

Fig.8. Effectiveness of water production.

\section{CONCLUSIONS}

We can concluded that by increase in distance between the basins edge and the inner edge of the glass cover an increase occurs in the percentage of temperature difference with maximum value was $52 \%$ at distance $9 \mathrm{~cm}$ from each edge, an increase occurs in the productivity with maximum productivity was $3.3 \mathrm{~L} / \mathrm{m}^{2}$ at distance $9 \mathrm{~cm}$ from each edge and an increase occurs in the efficiency with maximum efficiency was $70 \%$ at distance $9 \mathrm{~cm}$ from each edge. 
PROCESS ENGINEERING

\section{5- REFERENCES}

Abdelouahab B. and A. Rahmani (2017) "Thermal modeling of a basin type solar still enhanced by a natural circulation loop".

Bhupendra G., K. M. Tonish, J. E. Pankaj and M. Pandya (2013) "Thermal Modeling and Efficiency of Solar Water Distillation: A Review". American Journal of Engineering Research (AJER). Volume-2, Issue-12, 203-213

Kabeel A. E., Z. M. Omara and F. A. Essa (2014) Enhancement of modified solar still integrated with external condenser using nanofluids: An experimental approach. Energy Converse. Manage. 78, 493 - 498.

Khalifa A. N. (2011) On the effect of cover tilt angle of the simple solar still on its productivity in different seasons and latitudes. Energy Conversion and Management 52 : 431-436.

Sharshir S. W., Nuo Yang, GuilongPeng and A. E. Kabeel (2015) "Factors affecting solar stills productivity and improvement techniques: A detailed review". 1 - 35 .

Tiwari A. K. and G.N. Tiwari (2007) Thermal modeling based on solar fraction and experimental study of the annual and seasonal performance of a single slope passive solar still: the effect of water depths. Desalination 207, 184-204.

Velmurugan V. and K. Srithar (2011) Performance analysis of solar stills based on various factors affecting the productivity-A review. Renewable and Sustainable Energy Reviews 15: 12941304.

Yahya S. (2011) "Simulation Model for Seawater Distillation by Solar Energy". Ph.D. Thesis submitted to the Department of Agricultural Engineering, Faculty of Agriculture, Menoufia University, Egypt.

Zotalis K., E. G. Dialynas, N. Mamassis and A. N. Angelakis (2014) "Desalination Technologies: Hellenic Experience". 


\section{الملخص العربى الموني \\ دراسة بعض العوامل المؤثرة على انتاجية مقطرات شمسية المعابة

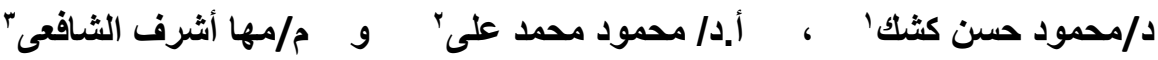

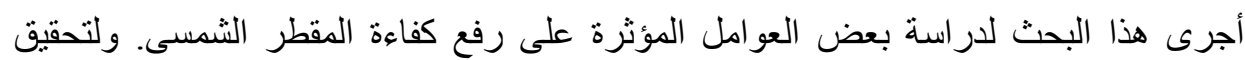

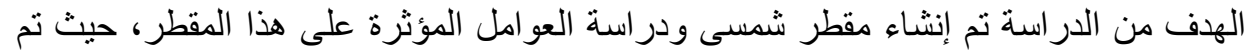

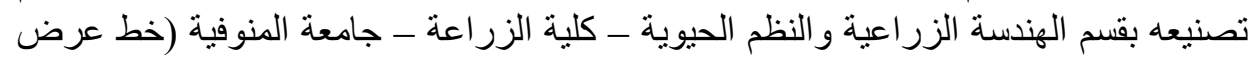

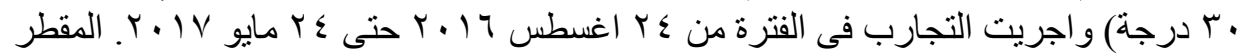

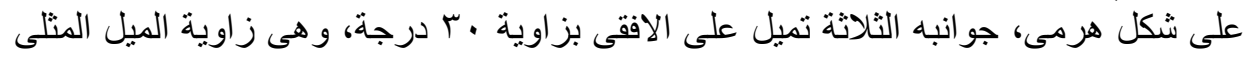

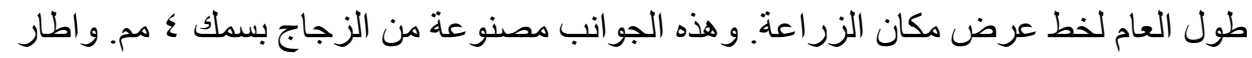

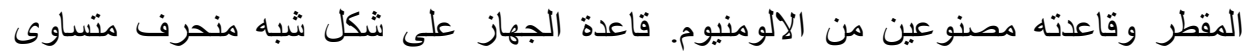

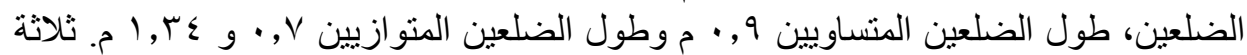

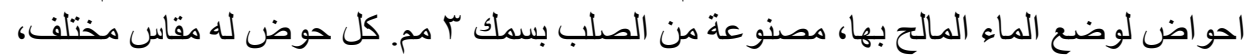

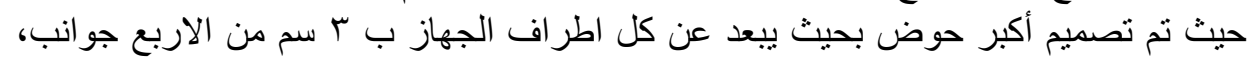

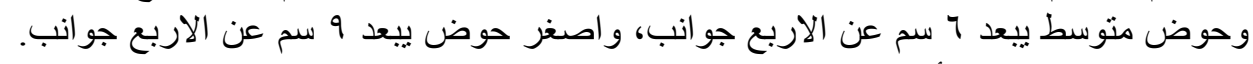

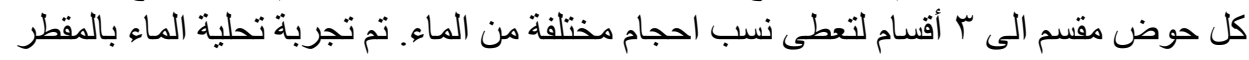

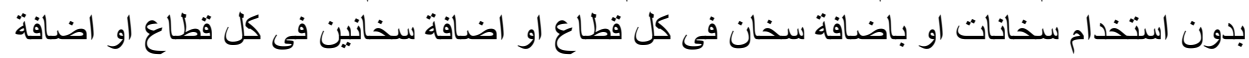

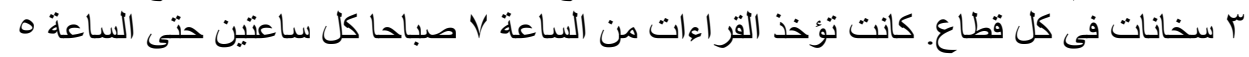

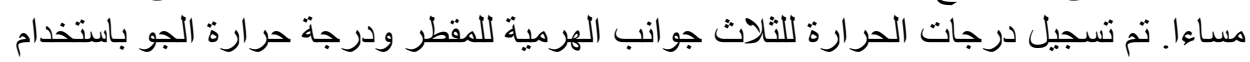

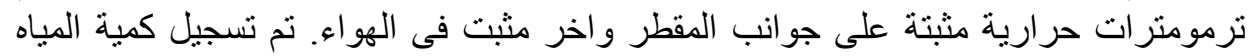

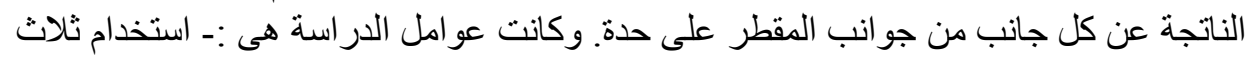

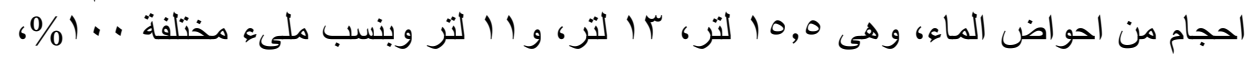

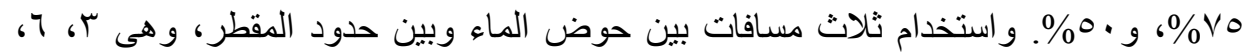

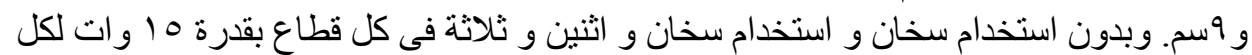

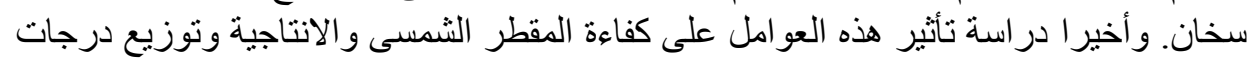
الحر ارة. وتوصلت الدراسة الى النتائج الآتية:-

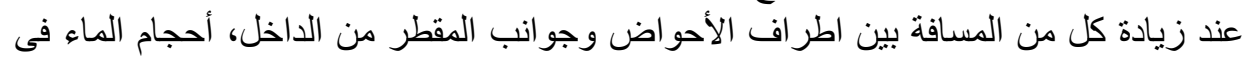

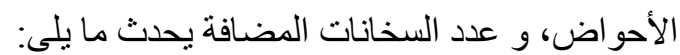

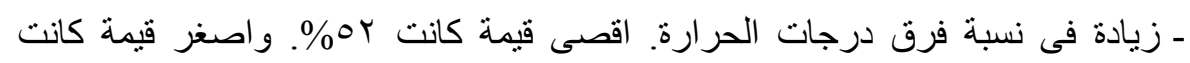

$$
\% 10
$$

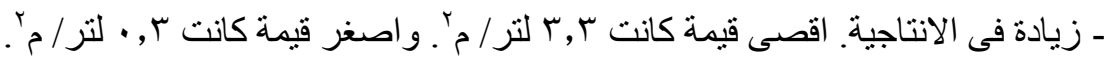

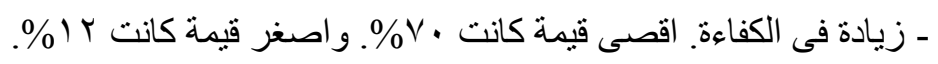

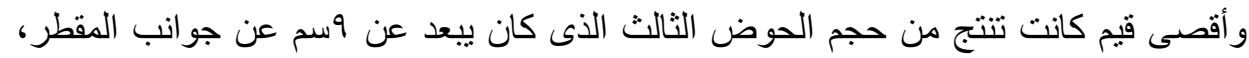

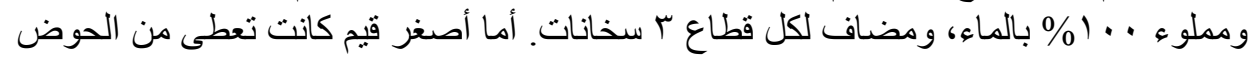

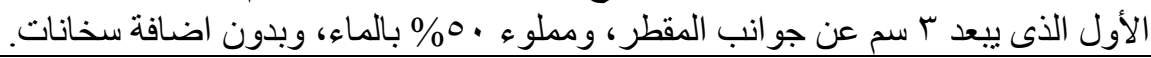

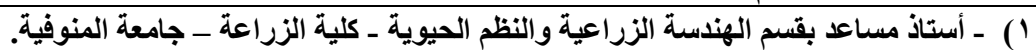

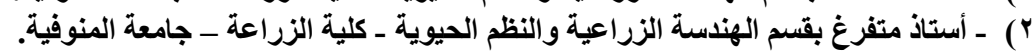

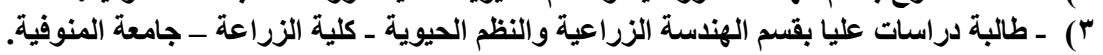

